\title{
Bark- and wood-boring beetles on Scots pine logging residues from final felling: Effects of felling date, deposition location and diameter of logging residues
}

\author{
J. Foit
}

Foit J., 2015. Bark- and wood-boring beetles on Scots pine logging residues from final felling: effects of felling date, deposition location and diameter of logging residues. Ann. For. Res. 58(1): 67-79.

Abstract. To reduce the risk of bark- and wood-boring beetle pests, the extensive removal of logging residues is conducted in forests; however, this practice can lead to a loss of saproxylic insect diversity. Thus, finding a better pest management strategy is needed and requires additional information on the actual effects of various, differently treated logging residues for pest multiplication. In the present study, a total of 2,160 fragments of Scots pine (Pinus sylvestris L.) logging residues generated during final felling in a single stand in the Drahanská Highlands in the Czech Republic were examined for bark- and wood-boring beetles. The felling occurred on four dates in 2006 (in February, May, August and November). The logging residues from each felling were left scattered on the clear-cut area or were gathered into piles. The fauna inhabiting the logging residues were investigated by peeling off the bark during the first six months of the vegetative period following the felling. The logging residues hosted species-rich assemblages of bark- and wood-boring beetles ( 25 species were identified). Beetle occurrence was significantly affected by felling date, logging residue type (trunk fragment or branch and branch thinner or thicker than $1 \mathrm{~cm}$ ), diameter and the manner in which the logging residues were deposited (freely scattered, top pile layer, or bottom pile layer). The Scots pine logging residues were a substrate for the significant multiplication of several potentially significant pests (particularly, Pityogenes chalcographus [Linnaeus], Ips acuminatus [Gyllenhal] and Pityophthorus pityographus [Ratzeburg]). The results indicated that the risk of pest reproduction can be minimised by felling the trees in August (and probably also September and October). For I. acuminatus and P. pityographus, the risk can be minimised by gathering the logging residues into piles. Keywords branch, pest, pile, Pinus sylvestris, saproxylic beetle, treetop

Authors. Jiř́i Foit (foit.jiri@gmail.com) - Department of Forest Protection and Wildlife Management, Faculty of Forestry and Wood Technology, Mendel University in Brno, Zemědělská 3, 61300 Brno, Czech Republic.

Manuscript received October 22, 2014; revised December 25, 2014; accepted January 04, 2015; online first January 30, 2015. 


\section{Introduction}

Logging residues (LRs) form a substantial portion of the dead wood in managed forests. Most LRs are produced during the final felling. Although LRs from final fellings do not include substrates with thick bark, a variety of thin-barked substrates with a wide range of diameters (i.e., from the thinnest branches with diameters of less than $1 \mathrm{~cm}$ to thick tree tops with diameters exceeding $7 \mathrm{~cm}$ ) are found. Moreover, LRs (as well as stumps) from final fellings generally experience high exposure to the sun, whereas most of the dead wood in managed forests is shaded; thus, these substrates are specific and important for many saproxylic beetles (Jonsell 2008a, b, Bouget et al. 2012, Jonsell \& Schroder 2015). Additionally, LRs from final fellings can serve as substrates for the development of forest bark- and woodboring pests (particularly bark beetles), and in specific circumstances, these LRs facilitate pest multiplication and outbreaks (Schroeder 2008). Therefore, various strategies for the removal of LRs (e.g., hauling, burning, and chipping) are often recommended to prevent pest multiplication (DeGomez et al. 2008). However, the extensive removal of LRs can lead to the extinction of rare saproxylic species and a loss of overall diversity, and the removal of sun-exposed LRs from final fellings might be of particular significance (Jonsell et al. 2007, Jonsell 2008a, b, Fossestøl \& Sverdrup-Thygeson 2009, Bouget et al. 2012, Jonsell \& Schroder 2015).

A necessary prerequisite to finding a way to decrease the risk of multiplication of barkand wood-boring beetle (BWBB) pests on LRs without extensive LR removal is to increase the understanding of the ecology of BWBBs (or generally, saproxylic beetles), including how they are influenced by the date of LR production, the post-felling treatments of LRs and other characteristics. In general, the occurrence of saproxylic beetles on LRs or dead wood is affected by substrate characteristics, including substrate metric parameters, such as bark thickness (Zhang et al. 1993, Foit 2010) and diameter (Schiegg 2001, Lindhe \& Lindelöw 2004, Lindhe et al. 2005, Jonsell et al. 2007, Maňák 2007, Jonsell 2008b, Foit 2010). Sun exposure (Jonsell et al. 2004, Lindhe \& Lindelöw 2004, Lindhe et al. 2005, Jonsell 2008b), moisture (Wallace 1953, Larkin \& Elbourn 1964), decomposition stage (Wallace 1953, Vanderwel et al. 2006, Jonsell 2008b) and the presence of other organisms (Jonsell et al. 2005, Abrahamsson et al. 2008, Weslien et al. 2011) are of remarkable significance for the occurrence of saproxylic beetles in various substrates. Because of these associations, known breeding substrate requirements and timing of mating and egg laying of particular BWBB species (Schwenke 1972), it is possible that the colonisation of LRs by BWBBs is influenced by the date of LR production (felling date). This has been documented for several BWBB species that develop in Norway spruce (Picea abies L. [Karst.]) LRs resulting from pre-commercial thinning (Kula \& Kajfosz 2006, 2007) and in Scots pine (Pinus sylvestris L.) stumps (Foit 2012a). Furthermore, the felling date was found to strongly affect Pityogenes chalcographus (Linnaeus) occurrence on various Scots pine LRs (Foit 2012b). The postfelling deposition of LRs (i.e., left scattered or concentrated into piles) affected Ips pini (Say) occurrence on LRs from ponderosa pine ( $\mathrm{Pi}$ nus ponderosa P. \& C. Lawson) and lodgepole pine (Pinus contorta Dougl. ex Loudon) (Six et al. 2002) and influenced the occurrence and development success of $P$. chalcographus on Norway spruce LRs (Kacprzyk 2012).

The goals of this study were to investigate which BWBB species developed and multiplied on Scots pine LRs that were generated in a final felling and to assess the effects of various habitat variables, including the type and diameter of the LR fragments, the felling date, and the post-felling deposition of LRs, on the occurrence of the recorded species. 


\section{Materials and methods}

\section{Study site}

The research was conducted at a single stand in the southern Drahanská Highland in the Czech Republic. The climate is characterised by a mean annual temperature of $8.4-8.5^{\circ} \mathrm{C}$ and an average annual rainfall of approximately $580-590 \mathrm{~mm}$. The study stand $\left(49^{\circ} 16^{\prime} 01^{\prime \prime} \mathrm{N}\right.$ and $\left.16^{\circ} 37^{\prime} 15^{\prime \prime} \mathrm{E}\right)$ was 0.99 ha in area, between 370 and $400 \mathrm{~m}$ in elevation and located on a southeast- to southwest-facing slope with a gradient of approximately 10\%. The evenaged stand was 114 years old in 2006, when the final felling was conducted. The main canopy mainly comprised Scots pine (77\%), European larch (13\%, Larix decidua Mill.) and sessile oak (7\%, Quercus petraea [Matt.] Liebl.). Norway spruce, European hornbeam (Carpinus betulus L.) and European birch (Betula pendula Roth) were also present. The forests in the study area were traditionally managed using a clear-cutting system and the prevailing artificial regeneration.

\section{Sampling}

The study stand was divided into four sections of equal area, and the felling was conducted on a different date in each section. The felling dates were $10^{\text {th }}$ February, $11^{\text {th }}$ May, $14^{\text {th }}$ August and $10^{\text {th }}$ November 2006. With each felling, LRs were produced from 40 (or slightly more) pine trees. All of the trees were removed from the felled site, creating a sun-exposed clear-cut area. Logging residues on approximately onequarter of the felled area were left scattered, whereas the remaining LRs were concentrated into piles (approximately $1.5 \mathrm{~m}$ high and $2 \mathrm{~m}$ wide).

Sampling began 14 days after felling and was repeated every 14 days within the vegetative period (23 $3^{\text {rd }}$ April through $10^{\text {th }}$ October) until 12 repetitions were performed in each section with a different felling date. On each sampling date, in each section of the stands felled on different dates, ten branches $(2-5 \mathrm{~cm}$ in diameter) and five trunk fragments from tree tops $(1 \mathrm{~m}$ in length and $5-18 \mathrm{~cm}$ in diameter) were sampled from the following locations: i) freely scattered LR, ii) the top layer (approximately within $40 \mathrm{~cm}$ from the top) of LR piles, and iii) the bottom layer (approximately below $60 \mathrm{~cm}$ from the top) of LR piles. Consequently, 2,160 LR fragments (i.e., 360 branches and 180 trunk fragments in each of 4 sections of the stand) were sampled. Only branches that were at least $1 \mathrm{~m}$ in length and 2 $\mathrm{cm}$ in diameter at the base were sampled. Parts of the sampled branches that were less than 1 $\mathrm{cm}$ in diameter were sampled separately; a total of 3,600 samples was collected. The branch or trunk length and diameter were recorded for each sampled LR fragment. Each sample was entirely debarked, and the BWBB (phloemo-, xylo- and xylomycetophagous) species present were identified based on gallery characteristics or on the morphological traits of imagoes or larvae (Švácha \& Danilevsky 1986, 1987, 1988, Bílý 1989, Bense 1995, Pfeffer 1995). Furthermore, the gallery coverage of each species was evaluated on a semilogarithmic, sixdegree scale based on a visual estimation of the percentage of the area exploited by the species within the sample mantle $(<1 \%, 1-5 \%$, $6-25 \%, 26-50 \%, 51-75 \%$ and $>75 \%$, see Braun-Blanquet 1964).

Three temperature and humidity sensors (Minikin THi, EMS Brno) were used to determine the microclimate characteristics of the LR piles. Air temperature and relative air humidity were recorded hourly from April to September of 2007 and 2008 in the following locations: i) over the clear-cut area (a sensor was installed $0.4 \mathrm{~m}$ above the ground), ii) in the top layer of the LR pile (1.2 $\mathrm{m}$ above the ground) and iii) in the bottom layer of the pile ( $0.4 \mathrm{~m}$ above the ground). 


\section{Statistical analyses}

The frequency of occurrence of each species was expressed as the proportion of samples in which the species was present. For statistical analysis, the six-point scale of gallery coverage was represented by the following middle values of the percentage intervals: $0.5 \%, 3 \%$, $15.5 \%, 38 \%, 63 \%$ and $88 \%$. Canonical correspondence analysis (CCA) was used to assess the effects of the habitat variables on the species composition of the beetle assemblages. The CCA does not require normally distributed data, is not affected by the correlation of habitat factors, and assumes unimodal models for the relationships between the responses of each species to the habitat variables. This approach is appropriate for the data because a preliminary detrended correspondence analysis showed long gradient lengths ( $>3 \mathrm{SD}$ ) (ter Braak 1986, 1987). In the CCA, a Monte Carlo permutation test (Manly 2001) with 999 permutations was used to compute the significance of the relationships between the species responses and the habitat factors. All of the analyses were performed using CANOCO for Windows (ter Braak 1987). All of the recorded species were included in the analyses; however, to avoid an undesirably high influence of low-frequency species, rare species were down-weighted as a separate step of the analyses in CANOCO.

The non-normal distributions of data for the gallery coverage of particular species (tested using Shapiro-Wilk tests) could not be corrected by data transformation; therefore, nonparametric statistics were used for further analyses (Hollander \& Wolfe 1999). The statistical significance of differences and trends in the gallery coverage of particular species found in LRs with different characteristics was tested by Kruskal-Wallis tests and Spearman's correlation indices. If significant differences were found by the Kruskal-Wallis tests, then the Mann-Whitney $\mathrm{U}$ tests with critical $p$-values that were decreased by Bonferroni adjustment (i.e., critical $p=0.017,0.008$ for the comparison of three or four datasets, respectively) were used to identify the pairs of datasets with significant differences. All of these calculations were performed in Statistica 10.0 (StatSoft 2013).

\section{Results}

Of the 25 species of BWBB found in LRs (Figure 1), the family Curculionidae (15 species) was the most abundant. The majority of the curculionids (11 species) were bark beetles (Scolytinae), and P. chalcographus and Ips acuminatus (Gyllenhal) were encountered most frequently (Figure 1).

All of the studied habitat variables significantly affected the species composition of the BWBB assemblages, and together, the habitat variables explained $14.8 \%$ of the observed variance in the species' gallery coverage (Table $1)$. The variance explained by particular variables overlapped negligibly (Figure 2). Felling date was the most significant variable affecting the species composition of the BWBB assemblages. The type of LR (trunk fragment or branch and branch $<1 \mathrm{~cm}$ or $>1 \mathrm{~cm}$ ) and LR diameter also had comparably strong effects. The LR deposit type (scattered or piled and top pile or bottom pile layer) affected the composition of the BWBB assemblages considerably but to a lesser extent.

Particular taxa were associated with specific felling dates, deposition locations and LR diameters (Table 2, Figures 3, 4). All of the taxa found on at least $50 \mathrm{LR}$ fragments exhibited significant differences in the gallery coverage on LRs that were produced on different dates (Table 2), and particular taxa exhibited characteristic patterns (Figure 3). For example, the three most frequent species (I. acuminatus, P. chalcographus and Pityophthorus pityographus [Ratzeburg]) were found most often on LRs that were produced in February, somewhat less frequently on LRs produced from 


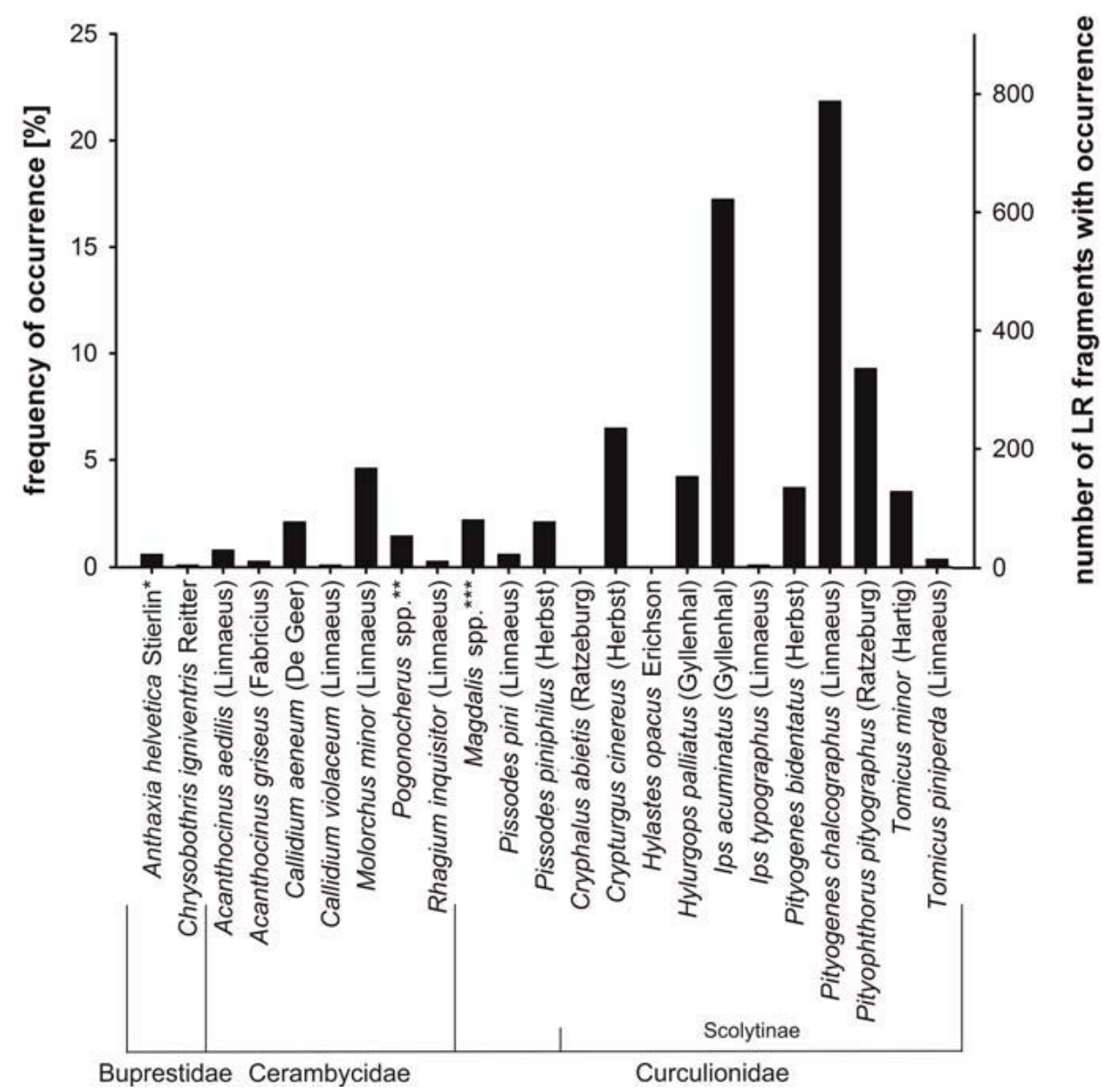

Figure 1 Frequency of taxa occurrence. *Includes mostly Anthaxia helvetica Stierlin; however, the occasional occurrence of other species from the subgenus Melanthaxia was possible. **Includes two species: Pogonocherus fasciculatus (De Geer) and Pogonocherus decoratus Fairmaire. ***Includes two species: Magdalis frontalis (Gyllenhal) and Magdalis rufa Germar.

Table 1 Canonical correspondence analysis. Results of the Monte Carlo permutation tests for the significance of the habitat factors for species composition of the BWBB assemblages. The percentage of the variance in the species' gallery coverage explained by the factors is included for particular cases. Values in parentheses show the results with the effects of specific variables removed by considering them covariables (listed in the last column)

\begin{tabular}{lllll}
\hline Factor & $F$ & $p$ & $\begin{array}{l}\text { Explained } \\
\text { variance [\%] }\end{array}$ & Covariables \\
\hline felling date & $\begin{array}{l}26.6 \\
(25.5)\end{array}$ & $\begin{array}{l}0.001 \\
(0.001)\end{array}$ & $7.3(6.5)$ & $\begin{array}{l}\text { LR type, diameter, LR deposit } \\
\text { type, sample date }\end{array}$ \\
\hline $\begin{array}{l}\text { LR type (trunk fragment or branch, } \\
\text { branch }<1 \text { or }>1 \mathrm{~cm})\end{array}$ & $\begin{array}{l}27.6 \\
(27.2)\end{array}$ & $\begin{array}{l}0.001 \\
(0.001)\end{array}$ & $5.2(4.7)$ & $\begin{array}{l}\text { felling date, LR deposit type, } \\
\text { sample date }\end{array}$ \\
\hline diameter & $\begin{array}{l}30.7 \\
(32.5)\end{array}$ & $\begin{array}{l}0.001 \\
(0.001)\end{array}$ & $3.0(2.8)$ & $\begin{array}{l}\text { felling date, LR deposit type, } \\
\text { sample date }\end{array}$ \\
\hline $\begin{array}{l}\text { LR deposit type (scattered, top pile } \\
\text { layer, or bottom pile layer) }\end{array}$ & $6.6(6.8)$ & $\begin{array}{l}0.003 \\
(0.003)\end{array}$ & $1.9(1.7)$ & $\begin{array}{l}\text { felling date, LR type, diameter, } \\
\text { sample date }\end{array}$ \\
\hline sample date & 9.6 & 0.001 & 0.1 & - \\
\hline factors combined & 17.4 & 0.001 & 14.8 & - \\
\hline
\end{tabular}




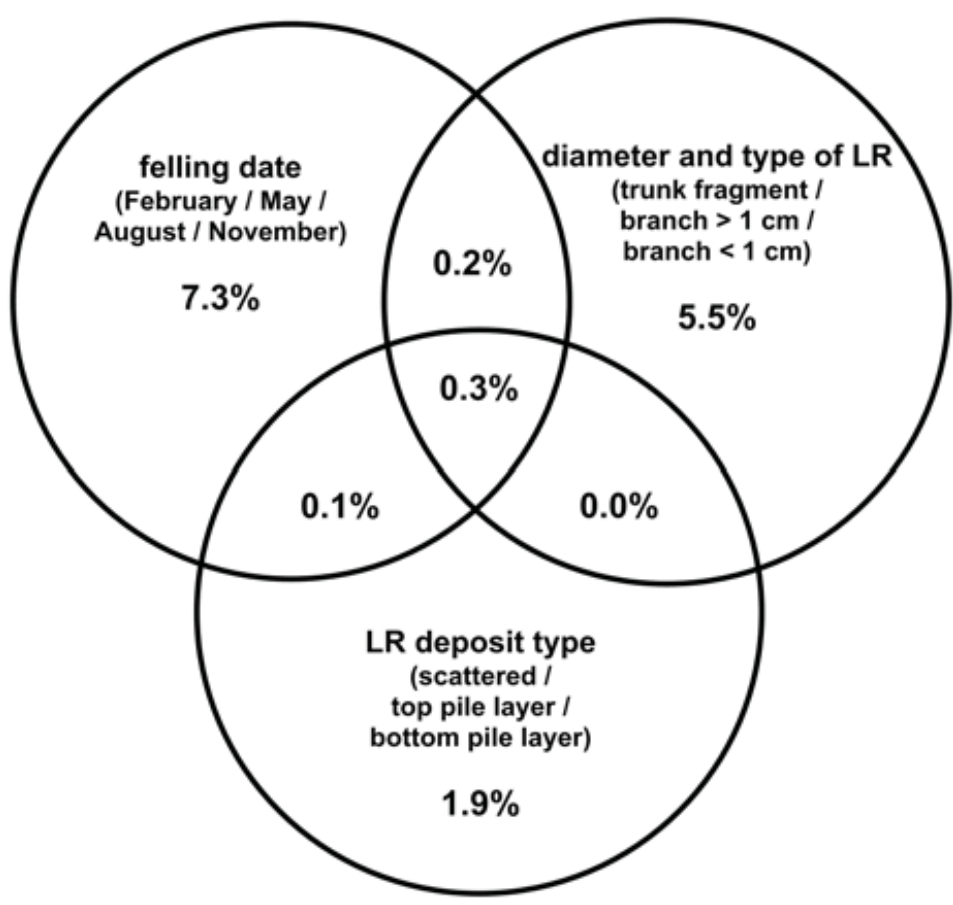

Figure 2 Venn diagram of the percentage values of the variance explained by the LR characteristics individually and jointly (circle overlaps) based on the canonical correspondence analysis (Table 1)

Table 2 The statistical significance of differences and trends in the gallery coverage of particular taxa on LRs with different characteristics. The differences in gallery coverage for particular species on LRs generated on different dates and for LR deposited in different ways were tested using the Kruskal-Wallis test. Spearman's correlation indices were used to illustrate the strength and significance of associations between the gallery coverage of particular species and LR diameter. Significant results $(p<0.05)$ are highlighted in bold. Only taxa recorded on at least 50 LR fragments were tested

\begin{tabular}{lccccc}
\hline & Felling date & \multicolumn{3}{c}{ LR deposit type } & Diameter \\
\cline { 2 - 6 } Taxon & KW-H & & KW-H & & $\begin{array}{l}\text { Spearman } \\
\text { correlation } \\
\text { index }\end{array}$ \\
\hline Callidium aeneum & $(3,3600)$ & $p$ & $(2,3600)$ & $p$ & $\mathbf{0 . 0 6 0}$ \\
Molorchus minor & $\mathbf{3 9 . 6}$ & $<\mathbf{0 . 0 0 1}$ & 4.5 & 0.105 & 0.031 \\
Pogonocherus spp. & $\mathbf{1 3 4 . 0}$ & $<\mathbf{0 . 0 0 1}$ & 2.6 & 0.267 & 0.031 \\
Magdalis spp. & $\mathbf{1 2 . 3}$ & $\mathbf{0 . 0 0 6}$ & $\mathbf{1 2 . 1}$ & $\mathbf{0 . 0 0 2}$ & $\mathbf{0 . 0 4 6}$ \\
Pissodes piniphilus & $\mathbf{5 7 . 0}$ & $<\mathbf{0 . 0 0 1}$ & 4.6 & 0.102 & $\mathbf{0 . 1 7 6}$ \\
Crypturgus cinereus & $\mathbf{9 8 . 4}$ & $<\mathbf{0 . 0 0 1}$ & $\mathbf{2 3 . 9}$ & $<\mathbf{0 . 0 0 1}$ & $\mathbf{0 . 3 2 2}$ \\
Hylurgops palliatus & $\mathbf{8 9 . 3}$ & $<\mathbf{0 . 0 0 1}$ & $\mathbf{2 6 . 3}$ & $<\mathbf{0 . 0 0 1}$ & $\mathbf{0 . 3 0 7}$ \\
Ips acuminatus & $\mathbf{1 7 . 4}$ & $<\mathbf{0 . 0 0 1}$ & $\mathbf{2 2 . 8}$ & $<\mathbf{0 . 0 0 1}$ & $\mathbf{0 . 3 7 3}$ \\
Pityogenes bidentatus & $\mathbf{1 0 3 . 0}$ & $<\mathbf{0 . 0 0 1}$ & $\mathbf{8 2 . 7}$ & $<\mathbf{0 . 0 0 1}$ & 0.013 \\
Pityogenes chalcographus & $\mathbf{3 4 . 6}$ & $<\mathbf{0 . 0 0 1}$ & $\mathbf{2 4 . 5}$ & $<\mathbf{0 . 0 0 1}$ & $\mathbf{0 . 2 7 7}$ \\
Pityophthorus pityographus & $\mathbf{1 2 2 . 3}$ & $<\mathbf{0 . 0 0 1}$ & 0.2 & 0.938 & $\mathbf{- 0 . 1 0 4}$ \\
Tomicus minor & $\mathbf{1 6 4 . 0}$ & $<\mathbf{0 . 0 0 1}$ & $\mathbf{4 1 . 2}$ & $<\mathbf{0 . 0 0 1}$ & $\mathbf{0 . 2 3 0}$ \\
\hline
\end{tabular}




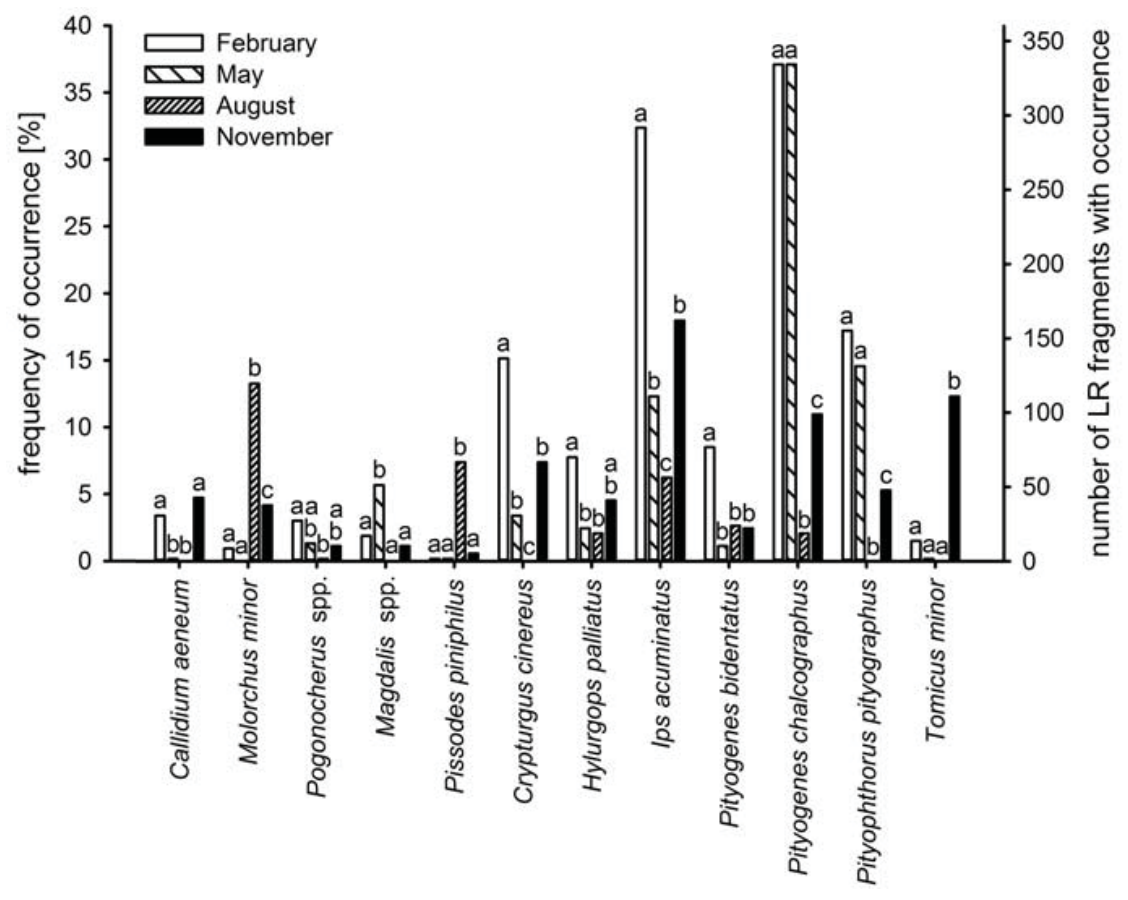

Figure 3 Frequencies of taxa occurrence according to felling date. Significant differences in gallery coverage were found for all taxa shown (Table 2). To determine between which pairs of datasets significant differences occurred columns representing datasets that did not differ significantly are labelled with the same letter. Only taxa recorded on at least 50 LR fragments are shown.

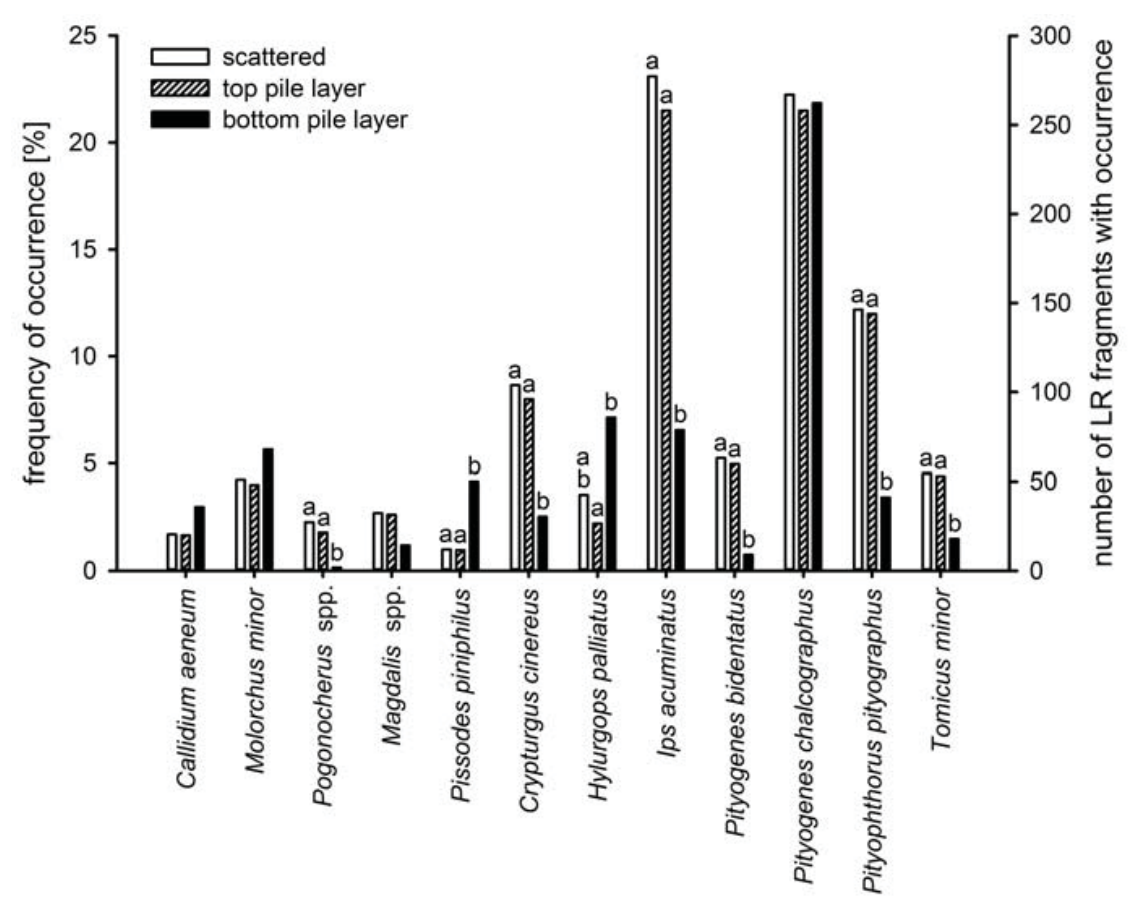

Figure 4 Frequencies of taxa occurrence according to LR deposit type. Columns belonging to taxa with significant differences in gallery coverage (Table 2) are labelled with letters to determine between which pairs of datasets significant differences occurred. Columns labelled with the same letter represent datasets that did not differ significantly. Only taxa recorded on at least 50 LR fragments are shown. 
May and November, and were nearly absent on LRs produced in August. In contrast, Molorchus minor (Linnaeus) and Pissodes piniphilus (Herbst) exhibited maximal frequencies on LRs produced in August. Furthermore, eight taxa had significantly different gallery coverage in relation to LR deposition (Table 2); for these taxa, differences were found only between LRs deposited in the bottom layer of piles and LRs deposited in the top layer of piles or left scattered (Figure 4). No significant differences were observed between LRs that were deposited in the top layer of piles and LRs that were left scattered. Although most of the taxa (Pogonocherus spp., Crypturgus cinereus [Herbst], I. acuminatus, Pityogenes bidentatus [Herbst], P. pityographus and Tomicus minor [Hartig]) significantly avoided LRs that were deposited in the bottom layer of piles, P. piniphilus and Hylurgops palliatus (Gyllenhal) were significantly more frequent in these LRs. Nine of the taxa found on at least 50 LR fragments were significantly associated with LR diameter (Table 2), and gallery coverage of most of the taxa increased with larger LR diameters (Callidium aeneum [De Geer], $P$. piniphilus, C. cinereus, H. palliatus, I. acuminatus, $P$. chalcographus and T. minor). Only Magdalis spp. and P. pityophthorus showed significant associations with the LRs of small diameter.

During the growing season, the mean air temperature in the top and bottom layers of the pile was 0.78 and $1.54^{\circ} \mathrm{C}$ lower than the temperature measured over the clear-cut area, respectively (Table 3 ). The mean relative air humidity in the top and bottom layers of the piles was 11.05 and $16.74 \%$ higher than those measured over the clear-cut area, respectively. Larger differences were found in the daily amplitudes; in the top and bottom layers of the pile, the amplitudes of the air temperature were on average $2.57^{\circ} \mathrm{C}$ and $7.11^{\circ} \mathrm{C}$ lower than those measured over the clear-cut area, respectively, and the amplitudes of the relative humidity in the top and bottom layers of the pile were on average $18.29 \%$ and $32.57 \%$ lower than those measured over the clear-cut area, respectively.

\section{Discussion}

Although the LRs from the final felling were formed only by branches and thin-barked top parts of trunks, the LRs served as a breeding substrate for a considerable number of BWBB species (Figure 1). The number of recorded species (25) was comparable to that found on whole standing mature Scots pine trees (17 species in Finland (Väisänen et al. 1993), 23 species in Poland (Zabecki 1999), and 34 species in the Czech Republic (Foit 2007, 2010)). The relatively high number of species recorded in the present study might be explained by the high sun-exposure of the LRs on the clearcut area because sun-exposure favours species richness among saproxylic beetles (Bouget \& Duelli 2004, Lindhe \& Lindelöw 2004, Lindhe

Table 3 Means of microclimatic characteristics measured in vegetative periods during 2007 and 2008 by sensors placed over the clear-cut area, in the top layer of the LR pile and in the bottom layer of the LR pile

\begin{tabular}{lllll}
\hline & \multicolumn{2}{c}{$\begin{array}{l}\text { Air temperature Relative air humidity } \\
{[\%]}\end{array}$} & $\begin{array}{l}\text { Daily amplitude of } \\
\text { air temperature } \\
{\left[{ }^{\circ} \mathrm{C}\right]}\end{array}$ & $\begin{array}{l}\text { Daily amplitude of } \\
\text { relative air humidity } \\
{[\%]}\end{array}$ \\
\hline Clear-cut area & 17.10 & 74.19 & 17.95 & 59.41 \\
Top layer of pile & 16.32 & 79.88 & 15.38 & 45.13 \\
Bottom layer of pile 15.56 & 90.93 & 10.84 & 26.84 \\
\hline
\end{tabular}


et al. 2005, Fossestøl \& Sverdrup-Thygeson 2009). This hypothesis was also supported by the much lower number of species (16) that was found in a similar study in the Czech Republic on shaded Scots pine LRs, which were generated by thinning (Foit 2011). Although no redlisted BWBB species were recorded, the high total number of species identified indicates that the saproxylic insect assemblages associated with these LRs are species rich and might be important for conservation. Additionally, several forest pests were recorded (Gregoire \& Evans 2004), primarily Ips acuminatus and P. chalcographus. Because these species were the most frequent species found in this study, it is clear that these pests multiplied significantly on the LRs generated by final felling. The main host tree species of $P$. chalcographus is Norway spruce (Pfeffer 1955, Schwenke 1972, Bertheau et al. 2009), although this species and I. acuminatus frequently develop on Scots pine LRs, which was previously documented at several localities in the Czech Republic (Foit 2012b).

All of the studied habitat factors (felling date, LR type, LR diameter and LR deposit type) significantly affected the composition of the BWBB assemblages and were together able to explain a substantial portion (14.8\%) of the variance in the species' gallery coverage (Table 1). Except for LR diameter and type, which are strongly correlated, the variables were almost independent, and the variance explained by these variables did not overlap considerably (Figure 2). Felling date had the highest explanatory power, and all of the species that occurred on at least 50 LRs exhibited significant differences in gallery coverage depending on LR generation date (Table 2, Figure 3). LR generation date was previously documented to have a substantial impact in various types of Norway spruce and Scots pine LR (Kula \& Kajfosz 2006, 2007, Foit 2012a, b) and is most likely associated with the timing of the species' mating and egg laying and with the requirements of particular species regarding stage of substrate dieback or decay. Thus, $P$. chalcographus, an early arriving species (Schwenke 1972, Gregoire \& Evans 2004, Foit 2014) that exhibits spring and early summer mating and egg laying, colonised fresh LRs immediately after felling. The overwintering generation primarily colonised LRs from February, and the following generation colonised LRs from May. In contrast, the LRs produced in August and November were not colonised in the year of felling, and the LRs were too wilted to attract $P$. chalcographus entering the next mating and egg-laying period (the LRs from August were particularly unattractive). Additionally, in a study conducted in the Czech Republic on various Scots pine LRs in 135 different stands (Foit 2012b), $P$. chalcographus obviously avoided Scots pine LRs produced during August and September (and partially also those produced during October and November). In the present study, $I$. acuminatus and P. pityographus were affected by felling date in a similar manner to that for P. chalcographus (Figure 3), which exhibits analogous mating and egg-laying periods. Because I. acuminatus colonised older LRs (from November and even August) somewhat more frequently, this species was likely slightly more tolerant of LR degradation. The only species with early spring mating and egg laying, $T$. minor, likely colonised moderately wilted LR from the November felling and avoided the LRs from February (too fresh) as well as the strongly degraded LRs from the previous May and August. Molorchus minor and $P$. piniphilus were the only species that preferred the LRs produced in August. A very early arriving species, P. piniphilus (Foit 2014), which mates and lays eggs throughout almost the entire vegetative period (Schwenke 1972), colonised LR from August immediately after it was generated. In contrast, M. minor, a late-arriving species (Schwenke 1972, Bense 1995, Foit 2014), colonised the strongly degraded LRs from August in the year following the felling. In addition to the felling date, the most impor- 
tant factors to affect the species composition of the BWBB assemblages were LR type and diameter (Table 1). Because these factors were strongly associated, the variance explained by them overlapped, as expected (Table 1, Figure $2)$. LR type had a greater explanatory power than LR diameter, possibly because LR type was more strongly correlated with unstudied variables, such as the presence or absence of needles on particular LR fragments. Substrate diameter has previously been shown to affect saproxylic beetle occurrence (Schiegg 2001, Lindhe \& Lindelöw 2004, Lindhe et al. 2005, Jonsell et al. 2007, Maňák 2007, Jonsell 2008b, Foit 2010, Brin et al. 2011). Thus, nine taxa were significantly associated with LR diameter in the present study (Table 2). The associations of particular taxa were approximately as expected based on their known substrate preferences (Schwenke 1972). Although most of the BWBB taxa preferred thicker LRs, two taxa were associated with thin LRs, and these associations with thin LRs were mostly weaker than those associated with thick LRs. However, the larger validity of this pattern is uncertain because whereas several studies conducted on saproxylic beetles found that higher species richness was associated with coarser, dead wood (Jonsell et al. 1998, Grove 2002, Jonsell et al. 2007), other researchers found more species associated with dead wood of small diameter (Schiegg 2001, Jonsell 2008b). LR deposit type also significantly affected the species composition of the BWBB assemblages, although this parameter had less effect than the other factors (Table 1). The effect of LR deposition has previously been demonstrated in a study conducted on Norway spruce in Poland (Kacprzyk 2012) and in a study conducted on lodgepole pine and ponderosa pine LRs in Montana (USA). The effects of LR deposition are caused mostly by modified microclimatic conditions within the LR piles and also by the decreased accessibility of LRs within the bottom layer of piles. No significant differences in the gallery coverage of particular species were found between the scattered LRs and the LRs that were deposited in the top layer of piles; similarity in climatic conditions (Table 3 ) and easy accessibility for BWBB represent likely explanations for this finding. In contrast, the gallery coverage of eight taxa significantly differed between LRs in the bottom layer of piles and the LRs deposited in top layer of piles or left scattered (Table 2, Figure 4). Most of the taxa found (Pogonocherus spp., C. cinereus, I. acuminatus, $P$. bidentatus, $P$. pityographus and T. minor) significantly preferred LRs that were scattered on the clear-cut area or that were deposited in the top layer of piles; this observation supported the hypothesis that high sunexposure and the consequent warmer microclimates increased saproxylic beetle diversity (Bouget \& Duelli, 2004; Lindhe \& Lindelöw, 2004; Lindhe, et al., 2005; Fossestol \& Sverdrup-Thygeson, 2009). Only P. piniphilus and $H$. palliatus were significantly more frequent in the LRs in the bottom pile layer. In the case of $H$. palliatus, this finding most likely reflected its requirement for higher humidity (Pfeffer 1955, Peltonen \& Heliövaara 1999). In contrast to the results obtained for Norway spruce LRs in southern Poland (Kacprzyk 2012), no significant differences were found in the gallery coverage of $P$. chalcographus according to LR deposition in the present study. Kacprzyk (2012) found a significantly lower occurrence of $P$. chalcographus in the bottom layer of LR piles, and this result might have reflected the more enclosed character of piles made of spruce LR and generally colder climate in that study area. Based on the results of Kacprzyk (2012) and my observations, P. chalcographus might have greater development success on LRs in piles (especially the middle layer) than on those that were left scattered.

\section{Conclusions and implications for forest management}

Logging residues produced during final fell- 
ing form a substantial part of the sun-exposed dead wood habitats in managed forests and provided a substrate for the development of a remarkable number of BWBB species in the present study, and thus, these residues most likely support many other saproxylic species. The occurrence of particular species and the overall species composition of the assemblages differed significantly among the studied LR types (trunk fragment or branch and branch $<$ $1 \mathrm{~cm}$ or $>1 \mathrm{~cm}$ ) and were strongly affected by the date of felling, substrate diameter and (to a lesser extent) LR deposit type (scattered, top pile layer, or bottom pile layer).

Additionally, the LRs generated from final felling enabled a number of pests to multiply, most notably, P. chalcographus, I. acuminatus and $P$. pityographus. However, the status of $P$. pityographus as a pest is disputed. Based on the results of the present study and those of Foit (2012b), we can infer that the risk of multiplication of these pests could be minimised if the fellings were conducted in August (and probably also in September or October). Furthermore, gathering the LRs into piles reduced the multiplication of particular pests (I. acuminatus, $P$. bidentatus, $P$. pityographus and $T$. minor). The only pest species that was found to favour piles was $P$. piniphilus, and significant multiplication of this pest is unlikely because of its low density on the LRs. The overall impact of LR pile formation on the multiplication of $P$. chalcographus remains unclear.

\section{Acknowledgements}

This study was supported by the OP Education for Competitiveness (European Social Fund and the state budget of the Czech Republic), Project No. CZ.1.07/2.3.00/30.0017 Postdocs in Biological Sciences at MENDELU. I appreciate the assistance of I. Březina with the experimental fellings.

\section{References}

Abrahamsson M., Lindbladh M., Ronnberg J., 2008. Influence of butt rot on beetle diversity in artificially created high-stumps of Norway spruce. Forest Ecology and Management 255(8-9): 3396-3403. DOI: 10.1016/ j.foreco.2008.01.010.

Bense U., 1995. Longhorn beetles: illustrated key to the Cerambycidae and Vesperidae of Europe. Margraf Verlag, Weikersheim, 512 p.

Bertheau C., Salle A., Roux-Morabito G., Garcia J., Certain G., Lieutier F., 2009. Preference-performance relationship and influence of plant relatedness on host use by Pityogenes chalcographus L. Agricultural and Forest Entomology 11(4): 389-396. DOI: 10.1111/j.14619563.2009.00442.x.

Bílý S., 1989. Krascovití (Buprestidae) [Buprestid beetles]. Academia, Praha, 111 p.

Bouget C., Duelli P., 2004. The effects of windthrow on forest insect communities: a literature review. Biological Conservation 118(3): 281-299. DOI: 10.1016/ j.biocon.2003.09.009.

Bouget C., Lassauce A., Jonsell M., 2012. Effects of fuelwood harvesting on biodiversity - a review focused on the situation in Europe. Canadian Journal of Forest Research-Revue Canadienne De Recherche Forestiere 42(8): 1421-1432. DOI: 10.1139/x2012-078.

Brin A., Bouget C., Brustel H., Jactel H., 2011. Diameter of downed woody debris does matter for saproxylic beetle assemblages in temperate oak and pine forests. Journal of Insect Conservation 15(5): 653-669. DOI: 10.1007/s10841-010-9364-5.

DeGomez T., Fettig C.J., McMillin J.D., Anhold J.A., Hayes C., 2008. Managing slash to minimize colonization of residual leave trees by Ips and other bark beetle species following thinning in southwestern ponderosa pine. University of Arizona, College of Agriculture and Life Sciences, Tucson, Arizona, 12 p.

Foit J., 2007. The fauna of cambioxylophagous insects on Scots pine trees declined after spells of drought in 2003. Journal of Forest Science 53(7): 334-339.

Foit J., 2010. Distribution of early-arriving saproxylic beetles on standing dead Scots pine trees. Agricultural and Forest Entomology 12(2): 133-141. DOI: 10.1111/ j.1461-9563.2009.00461.x.

Foit J., 2011. Kambioxylofágní hmyz na borovici lesní - se zvláštním přihlédnutím $\mathrm{k}$ jeho vývoji na těžebním odpadu [Cambioxylophagous insects on the Scots pine trees with special focus on the insects' development on logging residues]. Ph.D. Thesis, Mendel University in Brno, Brno, $182 \mathrm{p}$.

Foit J., 2012a. Early-arriving saproxylic beetles developing in Scots pine stumps: effects of felling type and date. Journal of Forest Science 58(11): 503-512.

Foit J., 2012b. Felling date affects the occurrence of Pityogenes chalcographus on Scots pine logging residues. Agricultural and Forest Entomology 14(4): 383-388. 
DOI: $10.1111 / \mathrm{j} .1461-9563.2012 .00579 . x$.

Foit J., 2014. Colonization of disturbed Scots pine trees by barkand wood-boring beetles. Agricultural and Forest Entomology 16(2): 184-195. DOI: 10.1111/afe.12048.

Fossestøl K.O., Sverdrup-Thygeson A., 2009. Saproxylic beetles in high stumps and residual downed wood on clear-cuts and in forest edges. Scandinavian Journal of Forest Research 24(5): 403-416. DOI: 10.1080/028275 80903143871.

Gregoire J.C., Evans H.F., 2004. Damage and control of BAWBILT organisms an overview. In: Lieutier F., Day K. R., Battisti A., Gregoire J.-C., Evans H. F. (eds.), Bark and wood boring insects in living trees in Europe: a synthesis. Kluwer Academic Publishers, Dordrecht, Boston \& London, pp. 19-37. DOI: 10.1007/978-14020-2241-8 4 .

Grove S.J., 2002. Saproxylic insect ecology and the sustainable management of forests. Annual Review of Ecology and Systematics 33: 1-23. DOI: 10.1146/annurev.ecolsys. 33.010802.150507.

Hollander M., Wolfe D.A., 1999. Nonparametric statistical methods, $2^{\text {nd }}$ edition. Wiley, New York, $816 \mathrm{p}$.

Jonsell M., 2008a. The effect of biofuel harvest on biodiversity. In: Röser D., Asikainen A., Raulund-Rasmussen K., Stupak I. (eds.), Sustainable use of forest biomass for energy - A synthesis with focus on the Nordic and Baltic region. Springer, The Netherlands, pp. 129-154. DOI: 10.1007/978-1-4020-5054-1_6.

Jonsell M., 2008b. Saproxylic beetle species in logging residues: which are they and which residues do they use? Norwegian Journal of Entomology 55(1): 109122.

Jonsell M., Hansson J., Wedmo L., 2007. Diversity of saproxylic beetle species in logging residues in Sweden - Comparisons between tree species and diameters. Biological Conservation 138(1-2): 89-99. DOI: 10.1016/ j.biocon.2007.04.003.

Jonsell M., Nitterus K., Stighall K., 2004. Saproxylic beetles in natural and man-made deciduous high stumps retained for conservation. Biological Conservation 118 (2): 163-173. DOI: 10.1016/j.biocon.2003.08.017.

Jonsell M., Schroder F., 2015. Proportions of saproxylic beetle populations that utilise clear-cut stumps in a boreal landscape - biodiversity implications for stump harvest. Forest Ecology and Management in press.

Jonsell M., Schroeder M., Weslien J., 2005. Saproxylic beetles in high stumps of spruce: Fungal flora important for determining the species composition. Scandinavian Journal of Forest Research 20(1): 54-62. DOI: 10.1080 /02827580510008211.

Jonsell M., Weslien J., Ehnstrom B., 1998. Substrate requirements of red-listed saproxylic invertebrates in Sweden. Biodiversity and Conservation 7(6): 749-764. DOI: 10.1023/A: 1008888319031.

Kacprzyk M., 2012. Feeding habits of Pityogenes chalcographus (L.) (Coleoptera: Scolytinae) on Norway Spruce (Picea abies) L. (Karst.) logging residues in wind-damaged stands in southern Poland. International
Journal of Pest Management 58 (2): 121-130. DOI: 10.1080/09670874.2012.669077.

Kula E., Kajfosz R., 2006. Osídlování smrkového těžebního odpadu z jarní prořezávky kambioxylofágy ve vyšších nadmořských výškách Beskyd [Colonization of spruce logging debris from spring cleaning by cambioxylophagous insect at higher locations of the Beskids]. The Beskids Bulletin 19(1): 171-176.

Kula E., Kajfosz R., 2007. Colonization of spruce logging debris from summer and autumn cleaning by cambioxylophagous insect at higher locations of the Beskids. The Beskids Bulletin 20(1): 193-198.

Larkin P.A., Elbourn C.A., 1964. Some observations on fauna of dead wood in live oak trees. Oikos 15(1): 7992. DOI: $10.2307 / 3564749$.

Lindhe A., Lindelöw Å., 2004. Cut high stumps of spruce, birch, aspen and oak as breeding substrates for saproxylic beetles. Forest Ecology and Management 203(1-3): 1-20. DOI: 10.1016/j.foreco.2004.07.047.

Lindhe A., Lindelöw Å., Asenblad N., 2005. Saproxylic beetles in standing dead wood density in relation to substrate sun-exposure and diameter. Biodiversity and Conservation 14(12): 3033-3053. DOI: $10.1007 /$ s10531-004-0314-y.

Maňák V., 2007. Saproxylic beetles in two types of fine woody debris of Norway spruce. Master Thesis, Department of Ecology, Swedish University of Agricultural Sciences, Upsala, $16 \mathrm{p}$.

Manly B.F.J., 2001. Randomization and Monte Carlo methods in biology. Chapman \& Hall, London, 281 p.

Peltonen M., Heliövaara K., 1999. Attack density and breeding success of bark beetles (Coleoptera, Scolytidae) at different distances from forest-clearcut edge. Agricultural and Forest Entomology 1(4): 237-242. DOI: 10.1046/j.1461-9563.1999.00033.x.

Pfeffer A., 1955. Kůrovci (Coleoptera: Scolytidae) [Scolytid beetles (Coleoptera: Scolytidae)]. Nakladatelství Československé Akademie Věd, Praha, 324 p.

Pfeffer A., 1995. Zentral- und Westpalaarktische Borkenund Kernkafer (Coleoptera, Scolytidae, Platypodidae). Pro Entomologia, Naturhistorisches Musem Basel, Basel, $310 \mathrm{p}$.

Schiegg K., 2001. Saproxylic insect diversity of beech: limbs are richer than trunks. Forest Ecology and Management 149(1-3): 295-304. DOI: 10.1016/S03781127(00)00563-6.

Schroeder L.M., 2008. Insect pests and forest biomass for energy. In: Röser D., Asikainen A., Raulund-Rasmussen K., Stupak I. (eds.), Sustainable Use of Forest Biomass for Energy - A Synthesis with Focus on the Nordic-Baltic Region. Springer, The Netherlands, pp. 109-128. DOI: 10.1007/978-1-4020-5054-1_5.

Six D.L., Vander Meer M., DeLuca T.H., Kolb P., 2002. Pine engraver (Ips pini) colonization of logging residues created using alternative slash management systems in Western Montana. Western Journal of Applied Forestry 17(2): 96-100.

StatSoft I., 2013: Electronic statistics textbook. OK: Stat- 
Soft, Tulsa. Web: www.statsoft.com/textbook/http:// www.statsoft.com/textbook/. Accesed: 30 September, 2014.

Švácha P., Danilevsky M.L., 1986. Cerambycoid larvae of Europe and Soviet Union (Coleoptera: Cerambycoidea), Part I. Acta Universitatis Carolinae - Biologica 30 (1-2): 1-176.

Švácha P., Danilevsky M.L., 1987. Cerambycoid larvae of Europe and Soviet Union (Coleoptera : Cerambycoidea), Part II. Acta Universitatis Carolinae - Biologica 31(3-4): 1-284.

Švácha P., Danilevsky M.L., 1988. Cerambycoid larvae of Europe and Soviet Union (Coleoptera : Cerambycoidea), Part III. Acta Universitatis Carolinae - Biologica 32 (1-2): 1-205.

ter Braak C.J.F., 1986. Canonical correspondence-analysis - a new eigenvector technique for multivariate direct gradient analysis. Ecology 67(5): 1167-1179. DOI: 10.2307/1938672.

ter Braak C.J.F., 1987. A Fortran program for community ordination by (partial) (detrended) (canonical) correspondence analysis, principal components analysis and redundancy analysis (version 2.1). Agricultural Mathematics Group, Wageningen, $95 \mathrm{p}$.

Väisänen R., Biström O., Heliövaara K., 1993. Subcortical Coleoptera in dead pines and spruces - is primeval species composition maintained in managed forests? Biodiversity and Conservation 2(2): 95-113. DOI: 10.1007/
BF00056127.

Vanderwel M.C., Malcolm J.R., Smith S.A., Islam N., 2006. Insect community composition and trophic guild structure in decaying logs from eastern Canadian pine-dominated forests. Forest Ecology and Management 225(13): 190-199. DOI: 10.1016/j.foreco.2005.12.051.

Wallace H.R., 1953. The ecology of the insect fauna of pine stumps. Journal of Animal Ecology 22(1): 154171. DOI: $10.2307 / 1698$.

Weslien J., Djupström L.B., Schroeder M., Widenfalk O., 2011. Long-term priority effects among insects and fungi colonizing decaying wood. Journal of Animal Ecology 80(6): 1155-1162. DOI: 10.1111/j.13652656.2011.01860.x.

Zabecki D.T., 1999. Podatność drzewostanów sosnowych na zasiedlanie przez owady kambio- i ksylofagiczne w rejonie Tarnobrzkiego Zagłębia Siarkowego [Susceptibility of pine stands to infestation by cambio- and xylophagous insects in the area of the Tarnobrzek Sulphur Basin]. Zeszyty Naukowe Akademii Rolniczej Im. H. Kołłataja w Krakowe, Rozprawy 254 1-98.

Zhang Q.H., Byers J.A., Zhang X.D., 1993. Influence of bark thickness, trunk diameter and height on reproduction of the longhorned beetle, Monochamus sutor (Col, Cerambycidae) in burned larch and pine. Journal of Applied Entomology - Zeitschrift Für Angewandte Entomologie 115(2): 145-154. 
